Oleksandra Berhilevych,

D.Sc., Professor, Sumy State University, Ukraine

(iD) ORCID ID, 0000-0002-3622-8942

email: o.bergylevych@med.sumdu.edu.ua

Olha Chechet,

Ph.D., State Research Institute for Laboratory Diagnostics and Veterinary Sanitary Examination, Ukraine

ORCID ID, 0000-0001-5099-577

email: o.chechet@vetlabresearch.gov.ua

Victoria Kasianchuk,

D.Sc., Professor, Sumy State University, Ukraine

(iD) ORCID ID, 0000-0001-8313-2997

email: v.kasyanchuk@med.sumdu.edu.ua

Vladyslav Smiianov,

D.Sc., Professor, Sumy State University, Ukraine

(DORCID ID, 0000-0002-4240-5968

email:v.smiyanov@med.sumdu.edu.ua

Maksym Fritsak,

Swiss Federal Institute of Technology, Switzerland

email: mfritsak@student.ethz.ch

Correspondence author: o.bergylevych@med.sumdu.edu.ua

\title{
ENSURING PUBLIC HEALTH: MONITORING OF HORMONE RESIDUES IN POULTRY MEAT
}

Abstract. The study's main purpose of addressing the problem of hormone content in poultry meat is to analyze the literature and such an official approach as state monitoring for 2017-2020. Research has shown that hormones have not been used in poultry farming for more than 50 years in the EU, the USA, Canada and other countries. In addition, there are strict international laws, including in Ukraine, on the control of the use of hormones in poultry to ensure public health. The urgency of solving the scientific problem is that despite the above, in the literature for the last decades there are reports based on consumer surveys (from 40 to 60\%) on the negative impact of poultry meat on the content of hormones on their health. This negatively affects the consumption and image of poultry producers. Such trends are observed, including in Ukraine. This encourages the provision of scientifically sound information on this issue. The study of the content of hormones in poultry meat in the article is carried out in the following logical sequence: the analysis of international scientific literature on the content of hormones in poultry meat, as well as data from the State Statistics Service of Ukraine on the trend of poultry consumption and increased demand among consumers for this type of meat. In addition, the article analyzes the official data of state monitoring of residual hormones in poultry meat. The following methods became the methodological tools of the conducted research: analysis of literature sources for 10 years, the period of research of the state monitoring is chosen 2017-2020. The object of the study was the biased attitude of some consumers to the safety of poultry meat in terms of hormones, which arose as a result of the spread of the myth of the use of hormones in poultry. The subject of the research was the analysis of current literature data and the results of official national monitoring of the content of hormones in poultry meat. Research shows that as a result of constant strict official controls on the use of hormones in poultry and the inefficiency of their use for poultry producers, the latter amount of hormones is at a minimum physiological level that does not harm public health. Our state monitoring studies show proper state control and provide guarantees to consumers in the consumption of safe poultry meat. The results of this study can be useful for consumers, scientists, and students in the field of food safety and our country as a whole to disseminate scientifically sound information in the field of state control over food safety.

Keywords: safety, poultry meat, hormones, state monitoring, risk assessment.

Cite as: Berhilevych, O., Chechet, O., Kasianchuk, V., Smiianov, V., \& Fritsak, M. (2021). Ensuring Public Health: Monitoring of Hormone Residues in Poultry Meat. Health Economics and Management Review, 3, 19-26. http://doi.org/10.21272/hem.2021.3-02

19 
Introduction. There are no safe food products because each of them contains some potentially hazardous substances for human health. Currently, this problem is solved by conducting state management of food risks to ensure safety for public health. Food risk management at the state level in the EU, USA, Canada, Japan and other countries, including Ukraine, is carried out at the legislative level. Food legislation establishes mandatory rationing of hazardous substances in food to those levels that are the lowest risk to human health and mandatory monitoring of residues of these substances in raw materials and food products to establish compliance with established standards. Thus, managing food risks for public health is a political challenge. Methodologically, management of food risk is carried out by the method of risk management and the method of risk assessment. Risk management is the process of selecting appropriate country-specific regulatory actions that are socially and economically acceptable and must be based on a scientific basis, which is called risk assessment (EC, 2010; Jeong et al., 2010; Passantino, 2012; Donovan, 2015). The risk assessment determines the level of exposure on the health of people or population groups to hazardous substances in food based on scientific evidence. Scientificbased risk assessment includes four stages. One of them is the analysis of the hazard level of a certain substance for human health. It is usually not difficult to assess the relationship between consumption of certain hazardous substances and poisoning in humans when clinical symptoms are immediate. It is more difficult to determine the risks associated with chemical exposure when the effect does not occur quickly.

One of such chemical risks in foods is hormones and hormone-like substances used as animal growth promotant and muscle development. In the EU, the use of hormones and hormone-like substance swith action to stimulate the growth of farm animals is prohibited according to Council Directive 96/22/EC and their monitoring must to be done according to Council Directive 96/23/EC. Despite the ban on hormones in animal husbandry, there is literature data on their possible use in meat production (Jeong et al., 2010; Matraszek-Zuchowska et al., 2017; Ibrahim et al., 2018). In some countries, Canada, Australia, and the USA, hormones such as oestradiol, testosterone, progesterone, and their esters are authorized. In addition, the consumer can get imported poultry meat from countries where there is no ban on the use of certain hormones. Therefore, monitoring of these substances by the state is mandatory. Monitoring the residues of hazardous chemicals in food raw materials and products is an effective method of preventing food risks in the public health system. National monitoring of chemical residues in food is used to inform national decision-making to protect public health (Jeong et al., 2010).

Based on the analysis of literature sources and evaluation of the results of state monitoring for 20172020 , provide a reasonable conclusion on the level of safety of poultry meat by the level of hormones in it to ensure public health.

Literature review. It should be noted that poultry is one of the leading industries in the world, among other types of meat production. Poultry meat is a relatively cheap and biologically complete food for humans. This is especially true of broiler meat, which is precocious and pleasant to the taste. Poultry meat has a high nutritional value, excellent dietary qualities and taste. Poultry meat contains all essential amino acids, fat, macro- and microelements, vitamins. More than $85 \%$ of the protein in poultry muscle is complete. Poultry fat has more unsaturated fatty acids and is low in cholesterol (Koomkrong et al., 2015; Soglia et al., 2016; Devatkal et al., 2019).

According to the FAO review, world poultry meat production reached 133.3 million tonnes in 2020 , up 1.3 \%year-on-year. Despite the challenging production and trading environment, the poultry sector encountered during the COVID-19 crisis in the world, this growth was an achievement. Poultry meat's relative affordability and shorter production cycle were the two critical enabling factors contributing to the sector's better performance than the bovine and pig meat sectors. Among the major producers of poultry meat in the world is China. China's production of this type of meat for 2020 pegged at 22 million tonnes, $5.3 \%$ more than in 2019. In the United States, poultry meat production rose by $1.15 \%$ to 23 million tons, in Brazil - by $1.6 \%$ - to 14 million tons. Poultry production in the EU also increased (0.5\%), although less 
than in 2019, reflecting a decline in domestic demand In Ukraine, according to the FAO, poultry production in 2020 increased by $4.11 \%$. Regarding world poultry meat exports in 2020, 14 million tonnes were principally driven by China, Brazil, the United States of America, Thailand, Argentina, the European Union, and Chile. The Democratic Republic of the Congo and Canada, among others, also increased poultry meat imports in 2020 (FAO, 2021; USDA, 2020; USDA, 2020a; Osadchuk et al., 2020). In Ukraine, as in most other countries, poultry meat is one of the most consumed types of meat and therefore poultry farming in Ukraine is one of the most intensive and dynamic branches of agricultural production. Chicken consumption in Ukraine is growing every year. If in the mid-2000s chicken meat accounted for $38 \%$ of total meat consumption (according to the Institute of Agrarian Economics), in recent years it ranks first among other meat products. On average, every Ukrainian eats about $24 \mathrm{~kg}$ of chicken, $15 \mathrm{~kg}$ of pork and $5.5 \mathrm{~kg}$ of beef a year. And more than $80 \%$ of consumption is accounted for by industrial chicken. More than two thirds of the live weight of all farm animals in Ukraine is occupied by poultry. About $30 \%$ of the produced poultry meat is exported. Almost all exports are chicken. The share of poultry meat in the consumption of all meat in Ukraine in 2019 exceeded 47\% (USDA, 2020; USDA, 2020a; Osadchuk et al., 2020).

Consumers of poultry meat in each country worry on the quality and safety of these products are a continuous issue for the poultry industry and its strategic future. In food animal production practice, farm owners use hormones or hormonal substances to improve body weight gain and increase the productivity of chickens. However, the use of these hormones eventually ends up with the occurrence of their residues in animal-originated food and it can be a risk factor for the occurrence of public health problems. Currently, different international and national regulatory bodies in each country have requirements, which enable them to implement residue monitoring test endeavors that safeguard the public and facilitate trading activity (Hirpessa et al., 2020). According to some scientists and poultry producers, there is no need for hormones in poultry because their use does not make sense. After all, the bird's body produces natural hormones that are transported into the bloodstream to regulate physiological responses such as growth, development and reproduction. This is due to the breed's characteristics, as well as a properly selected and balanced system of feeding chickens. For 60 years, scientists from several institutes around the world carefully selected modern poultry by a careful genetic selection of poultry on the desired traits, so that it is now much larger in weight than broiler chickens of the 1950s and in relatively small quantities. feed grows rapidly.

But in recent years, increased research information about the identification of hormones and hormonal growth-promoting agents in animal-originated food. The incidence of hormone residues in such types of food and food products beyond the tolerance acts as a risk factor for the occurrence of potential public health problems (Matraszek-Zuchowska et al., 2017; Ibrahim et al., 2018; Hirpessa et al., 2020).

Methodology and research methods. The methodology of literature data analysis was used in the article. The material was the results of scientific data published in articles on the public domain on the Internet in most of PubMed, using search keywords that reflect the subject of this article. The search for literature sources was conducted in from 2010 to the present. In addition, we analyzed the data of the review of conference materials, the topics of which were relevant to our study. An analysis of the results of the Plan of annual state monitoring of hormone residues in the muscles and liver of chickens for the period from 2016 to 2020, which were conducted on the basis of the State Research Institute for Laboratory Diagnostics and Veterinary Sanitary Examination. All regions of Ukraine were covered by state monitoring. The authors also compared these results with those of other international authors. Monitoring studies were performed at the State Research Institute for Laboratory Diagnostics and Veterinary Sanitary Examination in the Research Chemical and Toxicology Department. The institute is accredited in accordance with the requirements of DSTU ISO/IEC 17025: 2017 at the international level by the International Association for Laboratory Accreditation (ILAC MRA) in the field of testing and calibration. At the same time, the ILAC logo is placed on the expert opinions of the institute. It is assumed that a scientific evaluation of literature sources and results monitoring of hormone residues will contribute to the 
O., Berhilevych, O., Chechet, V., Kasianchuk, V., Smiianov, M., Fritsak. Ensuring Public Health: Monitoring of Hormone Residues in Poultry Meat

dissemination of results on a systematic basis state control of poultry meat safety in Ukraine to ensure public health, which will also have a positive effect on consumer confidence in the safety of meat birds and the positive image of our country at the international level.

Results. The official data of the State Statistics Service of Ukraine for 2016-2020 on the production of poultry and poultry meat to establish the trend of demand for this useful and cost-effective raw material for human nutrition was analysed (SSSU, 2020) (Table 1).

Table 1. Number of poultry of all kinds (as of January 1; thsd. heads)

\begin{tabular}{lcccc}
\hline \multicolumn{1}{c}{ Types of farms } & $\mathbf{2 0 1 7}$ & $\mathbf{2 0 1 8}$ & $\mathbf{2 0 1 9}$ & $\mathbf{2 0 2 0}$ \\
\hline $\begin{array}{l}\text { Poultry of all kinds number in all agricultural } \\
\text { holdings }\end{array}$ & 201668,0 & 204830,9 & 211654,4 & 220485,8 \\
\hline Poultry of all kinds number in enterprises & 109822,5 & 112512,3 & 118812,9 & 127773,2 \\
\hline Poultry of all kinds number in households & 91845,5 & 92318,6 & 92841,5 & 92712,6 \\
\hline Poultry of all kinds number in private farms & 2113,9 & 3177,5 & 4039,1 & 4535,2 \\
\hline
\end{tabular}

Sources: developed by the authors on the basis of (SSSU, 2020).

The data in Table 1 show an annual increase in the number of poultry of all kinds. Thus, in 2020 , the number of poultry of all species in farms of all categories compared to 2017 increased by $8.5 \%$, and compared to 2019 , on average, by $4 \%$. Most poultry of all species were raised in enterprises $-57.95 \%$, in second place in the number of all species of poultry are households $-40.0 \%$, and in private farms this indicator was only $2.05 \%$.

Table 2. Number of hens and cocks (as of January 1 ; thsd. heads)

\begin{tabular}{lcccc}
\hline \multicolumn{1}{c}{ Types of farms } & $\mathbf{2 0 1 7}$ & $\mathbf{2 0 1 8}$ & $\mathbf{2 0 1 9}$ & $\mathbf{2 0 2 0}$ \\
\hline $\begin{array}{l}\text { Total amount of hens and cocks } \\
\text { in all types of farms including: }\end{array}$ & 184335,9 & 186737,2 & 191967,9 & 202510,7 \\
\hline Enterprises with hens and cocks & 108012,3 & 110389,7 & 115280,8 & 125837,4 \\
\hline Households with hens and cocks & 76323,6 & 76347,5 & 76687,1 & 76673,3 \\
\hline
\end{tabular}

Sources: developed by the authors on the basis of (SSSU, 2020).

From the data in Tables 1 and 2 it can be concluded that the number of hens and cocks for the analysed period was much higher than other bird species. Thus, the number of hens and cocks in all types of enterprises in 2020 in relation to the total number of all species of poultry was $98.5 \%$, including, most of them were raised in enterprises $-62.14 \%$, and in households much less $-37.86 \%$.

The data in Table 2 show that each year during the analysed period there was an increase in the number of hens and cocks. Thus, compared to 2017, in 2020 in all types of farms there was an increase in the number of hens and cocks by $9 \%$, including in the enterprises of these species of poultry was more by $14.2 \%$, and in households - by $0.5 \%$.

Table 3. Poultry meat production (in slaughter weight; thsd.t)

\begin{tabular}{lcccc}
\hline \multicolumn{1}{c}{ Types of farms } & $\mathbf{2 0 1 6}$ & $\mathbf{2 0 1 7}$ & $\mathbf{2 0 1 8}$ & $\mathbf{2 0 1 9}$ \\
\hline All agricultural holdings & 1166,8 & 1184,7 & 1258,9 & 1381,4 \\
Enterprises & 992,4 & 1014,1 & 1084,6 & 1209,7 \\
\hline Types of farms & $\mathbf{2 0 1 6}$ & $\mathbf{2 0 1 7}$ & $\mathbf{2 0 1 8}$ & $\mathbf{2 0 1 9}$ \\
\hline Private farms & 25,1 & 27,2 & 33,3 & 40,4 \\
Household & 174,4 & 170,6 & 174,3 & 171,7 \\
\hline
\end{tabular}

Sources: developed by the authors on the basis of (SSSU, 2020). 
Analysing the data in Table 3, we can conclude that the production of poultry meat in 2019 as a whole increased by $15.5 \%$ compared to 2016 , including enterprises increased the production of poultry meat during this period by almost $18 \%$ of farms - by $37.9 \%$, and households reduced production by $1.6 \%$.

Analysis of the poultry industry in Ukraine from 2016 to 2020 showed that this industry is constantly evolving, increasing the amount of poultry meat consumed by the population. The development of poultry meat production is mainly due to large enterprises and there is a loss of position in this market of farms and households. This trend will continue. In such a situation, state control over poultry production, quality and safety is more effective because it is more likely to control large enterprises and ensure the use of good hygiene practices than in small farms. Effective state control over production is almost impossible in households and the provision of modern norms and standards for the safety of poultry meat. Poultry and poultry products are the most economical source of meat protein available to consumers. Currently, chicken prices are not very high compared to other types of meat, so it is considered social. Poultry production is cost effective because poultry (especially broilers) grow rapidly and gain weight. This efficiency is often misinterpreted by consumers as dangerous chicken production, as there is a myth that poultry are given hormones to achieve rapid growth with small amounts of feed. The effect of the possible risk of hormone content in meat products on consumer demand was studied by surveying. The results indicate that consumers underestimate the level of hormone intake with beef, but overestimate the level of risk from the use of hormones in chicken. Consumer concerns about the safety of hormone use are quite high. A study conducted by a team of researchers showed that $57 \%$ of consumers acknowledged that hormones in poultry meat pose a serious health risk. Although consumers are concerned about the use of hormones in meat animals, the results of these researchers show that most of them are not sufficiently aware of the actual use of hormones in meat production (Yang et al., 2020). Consumers have become more active in advocating the relationship between diet and health. They became interested in the peculiarities of food production, and the possible risks to their health. Some consumers have concerns that eating hormones from poultry with hormones can lead to cancer, as well as early menarche and premature sexual development in girls. In this article, we analyze whether there is a real basis for such consumer beliefs and whether poultry and meat products may be at risk of hormones. These issues need to be scientifically and reasonably covered (Newman et al., 2020). Concerns regarding the safety of animal originated products and the prevalence of public health hazards have grown according to the increased use of hormones and hormonal substances (Hirpessa et al., 2020). These hormones and hormonal substances could be steroid hormones and nonsteroidal products and synthetic chemicals which mimic hormone functions and are known for their interference on the function of the endocrine system. In addition to endocrine disturbances, hormones such as estrogen are known for their carcinogenicity, diethylstilbestrol is reported to have mutagenic, carcinogenic, immunotoxic, and teratogenic properties (Donovan 2015; Hirpessa et al., 2020). Physiological normally, hormones are endogenous biochemical components, which are produced by organs of the endocrine system to be released through the bloodstream and transported to target organs to stimulate or inhibit their function. Hormones can be grouped as steroidal and nonsteroidal (protein hormones) and $\beta$-agonists (clenbuterol, cimaterol, ractopamine, salbutamol, and zilpaterol), and the steroidal hormones are further subgrouped as anabolic steroids and corticosteroids (Hirpessa et al., 2020). Steroid hormones are active in the body when taken orally. However, protein hormones are broken down in the stomach and intensively metabolized after excretion from the intestine; they lose the ability to act in the body when swallowed. When feeding birds food with such hormones, they break down into amino acids in their body, as a result, hormones lose their function. The only way to maintain their hormonal action to stimulate growth is to introduce them to each bird almost daily. Such a procedure is impossible in the practice of modern poultry farming. Hormones are not cheap drugs, so their use is estimated, which can increase the price of final products. In addition to the cost of hormones, introducing them to millions of chickens requires high human labor costs, which further increases costs. To remain competitive, poultry uses minimal costs. 
Monitoring chemical residues in raw material of animal origin and food is an important aspect of public health. In Ukraine, annually, since 2004 and during this time State monitoring plan for residues of veterinary drugs and contaminants include hormones and hormonal substances is approved by the order of the State Service of Ukraine for Food Safety and Consumer Protection (SSUFSCP). This is done in order to get a general idea of the state of affairs regarding compliance of legislation on food products in Ukraine, the requirements of the European Union and other countries.

Implementation of the State Monitoring Plan is one of the most important tasks of state importance to ensure the safety of safe products of animal origin during laboratory tests to detect residual amounts of veterinary drugs, pesticides and contaminants (antibiotics, pesticides, hormones, radionuclides). This plan is approved following the requirements of the Laws of Ukraine «On Basic Principles and Requirements for Food Safety and Quality», «On state control over observance of the legislation on foodstuffs, animal feedstuffs, byproducts of animal origin, animal health and welfare» and subject to the requirements of Council Directive № 96/23/EC as amended by 2003 and 2008 (prohibiting the use in animal husbandry of certain substances having a hormonal or thyrostatic action and beta-agonists). This plan covers research on a large list of chemicals in food raw materials and food products. In poultry meat, this list includes: hormonal drugs, chloramphenicol, nitrofurans, nitromedazoles, a large list of antibacterial substances, carbamates, peritroids, nonsteroidal anti-inflammatory substances, organochlorine pesticides, mycotoxins, radionuclides and others. The authors analyzed the results of the implementation of the State Monitoring Plan for hormonal drug residues in poultry meat for 2016-2020. The research was performed by the staff of the State Research Institute for Laboratory Diagnostics and Veterinary Sanitary Examination in the Research Chemical and Toxicology Department. Samples of meat and liver of industrial chickens were taken for research from all regions of Ukraine. PX-MC-MC methods were used. In Ukraine between 2010 and 2020, 35387 samples taken throughout the country were examined for the presence of hormone residues. Testing has been conducted for identification of 18 hormones and hormone like substances from the following groups: 1) stilbenes (A1): diethylstilboestrol (DES), dienoestrol (DIE), and hexoestrol (HEX); 2) 2 - steroids (A3): 19-nortestosterone (19-NT), 17ß-oestradiol (E2); and 3) resorcylic acid lactones (RALs) (A4): zeranol (ZER); A5. Beta agonists: clenbuterol (CL), salbutamol, ractopamine, zilpaterol, cimaterol, brombuterol, clenbuterol, isoxsuprine, mapeneterol, terbutaline, ritodrine (Table 4).

The data of this table shows that the list of studies of poultry meat for hormones is expanding every year. So, in 2016, the list of hormones that were studied in the chicken was from 7, in 2019 and 18 - in 2020. This indicates continuous improvement in the laboratory diagnosis of hormones in poultry to implement state monitoring plans and minimize risks to public health. According to the results of studies on all types of hormones, it was found that in the samples of meat and liver of poultry, positive results were obtained, corresponding to the background minimum levels (corresponding to the natural level of hormones). Such results are not assessed as a positive risk to human health and are therefore treated as negative. According to the results of the conducted researches, the dangers of hormones for public health during the consumption of poultry meat have not been established. Our data coincide with similar data in most EU countries.

Table 4. The list of hormones for which the study of poultry meat was conducted in $2016-2020$ in Ukraine

\begin{tabular}{ccccc}
\hline $\mathbf{2 0 1 6}$ & $\mathbf{2 0 1 7}$ & $\mathbf{2 0 1 8}$ & $\mathbf{2 0 1 9}$ & $\mathbf{2 0 2 0}$ \\
\hline & & & \\
DES & DES & A1. Stilbenes & DES \\
DIE & DIE & DES & DIE & DIE \\
HEX & DIE & HEX & HEX \\
\hline
\end{tabular}


O., Berhilevych, O., Chechet, V., Kasianchuk, V., Smiianov, M., Fritsak. Ensuring Public Health: Monitoring of Hormone Residues in Poultry Meat

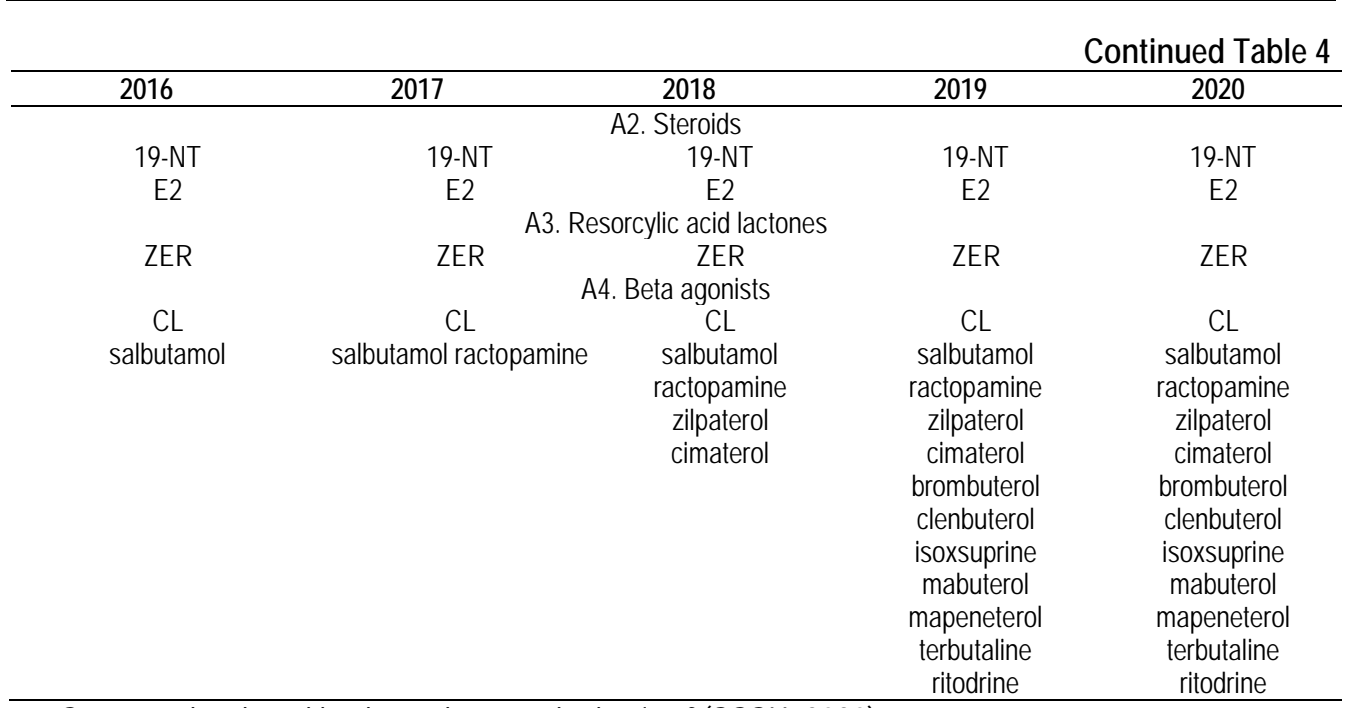

Sources: developed by the authors on the basis of (SSSU, 2020).

Conclusions. An important function of the State Monitoring of Veterinary Drug and Contaminant Residues plan, including hormone residues in poultry meat, is to ensure that the risks to public health do not reach unacceptable levels. The information obtained from the monitoring results is used to create a database and increase the country's effectiveness of risk management. The dangers of hormones for public health during the consumption of poultry meat have not been established. The main purpose of food risk management is to ensure that the two main activities for scientific risk assessment and monitoring of poultry products (meat) are given a gated focus that reduces or eliminates the risk factor in food intended for human consumption. Our research in the scientific literature provides evidence that hormone residues in poultry meat can have some adverse effects on human health. However, most scientists conclude that after the ban on hormones in poultry in the US, EU, and other countries, these substances in poultry meat are identified in small quantities that do not pose a threat to public health. There is no ban on the use of hormones in poultry in Ukraine, but given the official monitoring data, it can be concluded that the national chicken is safe for consumers' health in terms of hormone levels. Therefore, regular monitoring of hormone levels in poultry meat plays a vital role in ensuring safe nutrition and public health. An important function of official monitoring is to provide consumers with reliable information that chicken meat can be consumed without worrying about the negative effects of hormones.

Author Contributions: conceptualization, V. K.; formal analysis and data curation, O. Ch.; methodology, writing-review and editing, O. B. and M. F.; visualization and writing of original draft, V. S.

\section{References}

Council Directive 96/22/EC of 29 April 1996, concerning the prohibition on the use in stockfarming of certain substances having a hormonal or thyreostatic action and of $\beta$-agonists, and repealing Directives 81/602/EEC, 88/146/EEC and 88/299/EEC. Retrieved from [Link]

Council Directive 96/23/EC of 29 April 1996 on measures to monitor certain substances and residues thereof in live animals and animal products and repealing Directives 85/358/EEC and 86/469/EEC and Decisions 89/187/EEC and 91/664/EEC. Retrieved from [Link]

Devatkal, S. K., Naveena, B. M., \& Kotaiah, T. (2019). Quality, composition, and consumer evaluation of meat from slow-growing broilers relative to commercial broilers. Poultry science, 98(11), 6177-6186. [Google Scholar] [CrossRef]

Donovan, C. (2015). If FDA does not regulate food, who will? A study of hormones and antibiotics in meat production. American journal of law \& medicine, 41(2-3), 459-482. [Google Scholar] [CrossRef]

EC. (2009). Pharmacologically active substances and their classification regarding maximum residue limits in foodstuffs of animal origin. Retrieved from [Link] 

Residues in Poultry Meat

FAO. (2021). Meat market review: Overview of global meat market developments in 2020. [Link]

Hirpessa, B. B., Ulusoy, B. H., \& Hecer, C. (2020). Hormones and hormonal anabolics: residues in animal source food, potential public health impacts, and methods of analysis. Journal of Food Quality, 2020. [Google Scholar] [CrossRef]

Ibrahim, H. M., Amin, R. A., Diab, O. M., \& Hassan, A. E. (2018). Survey on some hormonal residues in chicken meat, liver and kidneys. Benha Veterinary Medical Journal, 34(2), 23-30. [Google Scholar]

Jeong, S. H., Kang, D., Lim, M. W., Kang, C. S., \& Sung, H. J. (2010). Risk assessment of growth hormones and antimicrobial residues in meat. Toxicological research, 26(4), 301-313. [Google Scholar] [CrossRef]

Koomkrong, N., Theerawatanasirikul, S., Boonkaewwan, C., Jaturasitha, S., \& Kayan, A. (2015). Breed-related number and size of muscle fibres and their response to carcass quality in chickens. Italian Journal of Animal Science, 14(4), 4145. [Google Scholar] [CrossRef

Matraszek-Zuchowska, I., Woźniak, B., Kłopot, A., Witek, S., Sielska, K., \& Posyniak, A. (2017). Control of anabolic hormone residues in tissues of slaughter animals in Poland during the period of 2011-2015. Journal of Veterinary Research, 61(1), 69-79. [Google Scholar] [CrossRef]

Newman, L., Mehlhorn, J., Tewari, R., \& Darroch, B. (2020). Consumer perception of antibiotic-free and hormone-free meat products. J Food Stud, 9(1), 80

Osadchuk, V., Shaidetska, V., \& Drobotiuk, O. (2020). Trends in the chinese poultry meat market: prospects for the Ukrainian exporters. Kitaêznavči doslidžennâ, 93-102. [CrossRef]

Passantino, A. (2012). Steroid Hormones in Food Producing Animals. In A Bird's-Eye View of Veterinary Medicine. IntechOpen. [Google Scholar]

Soglia, F., Mudalal, S., Babini, E., Di Nunzio, M., Mazzoni, M., Sirri, F., ... \& Petracci, M. (2016). Histology, composition, and quality traits of chicken Pectoralis major muscle affected by wooden breast abnormality. Poultry Science, 95(3), 651-659. [Google Scholar] [CrossRef].

SSSU. (2020). Animal production of Ukraine. Retrieved from [Link]

USDA. (2020). Livestock and Poultry: World Markets and Trade. Retrieved from [Link]

USDA. (2020a). Ukraine: Poultry and Products Annual. Retrieved from [Link]

Yang, R., Raper, K. C., \& Lusk J. L. (2020). Impact of Hormone Use Perceptions on Consumer Meat Preferences. Journal of Agricultural and Resource Economics, 45(1), 107-123. [CrossRef]

Олександра Бергілевич, д.вет.наук, професор, Сумський державний університет, Україна

Ольга Чечет, к.вет.н, Державний науково-дослідний інститут з лабораторної діагностики та ветеринарно-санітарної експертизи, Україна

Вікторія Касянчук, д.вет.наук, професор, Сумський державний університет, Україна

Владислав Сміянов, д.мед.наук, професор, Сумський державний університет, Україна

Максим Фріцак, Швейцарський федеральний технологічний інститут, Швейцарія

Забезпечення громадського здоров'я: моніторинг залишків гормонів у м'ясі птиці

Основною метою дослідження до вирішення проблеми вмісту гормонів у м'ясі птиці $\epsilon$ аналіз літературних джерел та такого офріційного підходу як державний моніторинг за 2017-2020рр. Результати досліджень показали, що в ЄС, США, Канаді та в інших країнах гормони не використовують у птахівниитві більше 50 років. Крім того, існує жорстке міжнародне законодавство, зокрема в Україні щодо контролю за використанням гормонів при вирощуванні птииі для гарантування громадського здоров'я. Актуальність вирішення наукової проблеми полягає в тому, що не дивлячись на вищезазначене, у літературних джерелах за останні десятки років існують повідомлення на основі опитувань про переконання споживачів (від 40 до 60\%) щодо негативного впливу м'яса птиці за умістом гормонів на їх здоров'я. Це негативно впливає на споживання та на імідж виробників м'яса птиці. Такі тенденції спостерігаються, зокрема ів Україні. Це спонукає до надання науково обгрунтованої інфоормації із цього питання. Дослідження питання вмісту гормонів у м'ясі птиці у статті здійснено в такій логічній послідовності: наведено аналіз даних міжнародної наукової літератури про вміст гормонів у м'ясі птиці, а також даних Державної служби статистики України про тенденцію споживання м'яса птииі. Констатовано збільшення попиту серед споживачів на чей вид м'яса. Крім иього, у статті проведено аналіз офріційних даних державного моніторингу залишкових кількостей гормонів у м'ясі птиці. Методичним інструментарієм проведеного дослідження стали такі методи: аналіз літературних джерел за 10 років, періодом дослідження державного моніторингу обрано 2017-2020 роки. Об'єктом дослідження обрано упереджене ставлення частини споживачів до безпечності м'яса птиці за умістом гормонів, яке виникло внаслідок поширення міфу про використання гормонів у птахівниитві. Предметом досліджень був аналіз сучасних літературних даних та результати оффіційного національного моніторингу щодо вмісту гормонів у м'ясі птиці. Результати досліджень свідчать про те, що в результаті постійного жорсткого офріційного контролю за використанням гормонів у птахівництві, а також неефективності їх використання для виробників м'яса птиці , в останньому кількість гормонів знаходиться на мінімальному фізіологічному рівні, який не несе шкоди громадському здоров'ю. Дослідження державного моніторингу свідчать про належний контроль з боку держави. Результати проведеного дослідження можуть бути корисними для споживачів, для науковиів, студентів щодо безпечності харчових продуктів, а також для країни цілому для поширення науково обгрунтованої інформації в галузі забезпечення державного контролю за безпечністю харчових продуктів.

Ключові слова: безпечність, м'ясо птиці, гормони, державний моніторинг, оцінка ризику 